\title{
Mycobacterium Tuberculosis Measurement
}

National Cancer Institute

\section{Source}

National Cancer Institute. Mycobacterium Tuberculosis Measurement. NCI Thesaurus.

Code C128982.

The determination of the amount of mycobacterium tuberculosis present in a sample. 